\title{
Chemical potential of gaseous medium for corundum single crystals growth
}

\author{
Ie.Kryvonosov, L.Lytvynov \\ Institute for Single Crystals, National Academy of Sciences of Ukraine, \\ 60 Nauky Ave., 61001 Kharkiv, Ukraine
}

\section{Received October 19, 2017}

\begin{abstract}
A method has been proposed for evaluation of the chemical potential $(\varepsilon)$ of the medium for corundum growth and annealing. It is based on the difference between aluminum and oxygen chemical potentials in corundum thermal dissociation products and technological medium. Disturbance of the anionic desstoichiometry of the crystal in the high-temperature carbon-containing medium is defined by lowered oxygen partial pressure over the crystal surface due to the interaction of corundum thermal dissociation products with carbon monoxide contained in the growth medium. The function $\left[V_{O}\right]=f(\varepsilon)$ has been determined, which makes it possible to calculate the chemical potential of the gas medium of the process equipment on the basis of data on the violation of stoichiometry of the grown (annealed) sapphire. Evaluated is the chemical potential of the gaseous medium for the grown and annealing of corundum single crystals for various technological systems.

Keywords: technological gaseous medium, chemical potential, Schottky defects, single crystals.

Предложен метод оценки химического потенциала $(\varepsilon)$ среды выращивания и отжига корунда. Метод основан на определении разницы химического потенциала алюминия и кислорода в продуктах термической диссоциации корунда и в технологической газовой среде. Нарушение анионной стехиометрии кристалла в высокотемпературной углеродосодержащей среде связано с пониженным парциальным давлением кислорода над поверхностью кристаллов в результате взаимодействия продуктов термической диссоциации корунда с оксидом углерода, содержащимся в газовой среде выращивания. Определена функция $\left[V_{O}\right]=f(\varepsilon)$, что позволяет на основании данных о нарушении стехиометрии выращенного (отожжённого) сапфира вычислить величину химического потенциала газовой среды технологического оборудования. Оценен химический потенциал газовой среды выращивания и отжига монокристаллов корунда для различных технологических систем.
\end{abstract}

Хімічний потенціал газового середовища вирощування монокристалів корунду. Є.Кривоносов, Л.Литвинов.

Запропоновано метод оцінки хімічного потенціалу $(\varepsilon)$ середовища вирощування та відпалу корунду. Метод базується на визначенні різниці хімічного потенціалу алюмінію і кисню у продуктах термічної дисоціації корунду та у технологічному газовому середовищі. Порушення аніонної стехіометрії кристала у високотемпературному вуглецевому середовищі пов'язано зі зниженим парціальним тиском кисню над поверхнею кристалів за рахунок взаємодії продуктів термічної дисоціації корунду з оксидом вуглецю, що міститься у газовому середовищі росту. Визначено функцію $\left[V_{\mathrm{O}}\right]=f(\varepsilon)$, що дає змогу на підставі порушення стехіометрії вирощеного сапфіру вираховувати величину хімічного потенціалу газового середовища для технологічного кристалізаційного та відпалювального обладнання, де використовується нагрівач і технологічне оснащення $з$ графіту. Оцінений хімічний потенціал газового середовища вирощування і відпалу монокристалів корунду для різних технологічних систем. 


\section{Introduction}

At present, corundum single crystals have found wide application in different fields of science and engineering. The presence of pin-defects in the crystal matrix and activator ions define important operating characteristics of corundum, such as its mechanical reliability and ray strength [1, 2], radiation stability [3], optical absorption [4], as well as generation characteristics of the solid laser active elements [5]. Nowadays, a direct influence on the crystal properties caused by the Schottky defects, viz. the vacancy disturbances of the crystal pattern order, is of a special interest, because this type of defects is more sensitive to the reduction and oxidation (redox) properties of the growth and annealing medium. At present corundum single crystals are grown by various technological methods. This defines the use of process gaseous media with different oxidation-reduction chemical potentials, which significantly affects the stoichiometry of the crystal and the charge state of the activator ions. Therefore, control of the chemical potential of the technological medium is an urgent task when growing high-quality crystals. The aim of the present work was to estimate the redox chemical potential of the high-temperature technological medium and to study its relation to the stoichiometry of corundum single crystals.

\section{2 .Influence of the gaseous medium chemical potential on the crystal matrix stoichiometry}

The chemical composition of the growth (annealing) atmosphere of a single crystal defines the stoichiometry of the latter and the charge state of the activator ions. Since high-temperature technological medium (for crystallization/annealing) is neutral to the crystal with thermodynamically equilibrium oxygen and aluminum atoms between the crystal and technological medium, the redox chemical potential of the medium $(\varepsilon)$ can be expressed through the chemical potentials of these atoms in the corundum thermal dissociation products $\left(\mu_{\mathrm{Al}}^{0}, \mu^{0} \mathrm{O}\right)$ and in the technological medium $\mu_{\mathrm{Al}}^{*}, \mu_{\mathrm{O}}^{*}[6]$ :

$$
\begin{aligned}
\varepsilon & =\frac{2}{3} \cdot\left(\mu_{\mathrm{Al}}^{0}-\mu_{\mathrm{Al}}^{*}\right)-\left(\mu_{\mathrm{O}}^{0}-\mu_{\mathrm{O}}^{*}\right)= \\
& =R T \cdot \ln \left[\left(\frac{P^{0_{\mathrm{Al}} \mathrm{l}}}{P^{*}{ }_{\mathrm{Al}}}\right)^{\frac{2}{3}} \cdot\left(\frac{P^{*} \mathrm{O}}{P^{0_{\mathrm{O}}}}\right)\right],
\end{aligned}
$$

where $R=8.3(\mathrm{~J} / \mathrm{mol} \cdot \mathrm{K})$ is the universal gas constant; $T$, the technological process temperature $(\mathrm{K}) ; P^{0}{ }_{\mathrm{Al}}, P^{0}$ o, the equilibrium partial pressures of aluminum and oxygen vapors in the corundum thermal dissociation products of the stoichiometric composition; $P^{*}{ }_{\mathrm{Al}}, P^{*}$, the partial vapor pressures of $A l$ and $O$ in the high-temperature technological medium.

The thermal dissociation products of corundum crystals consist mainly of atomic aluminum and oxygen vapors, their content being defined by the equilibrium constant of aluminum oxide dissociation:

$$
\mathrm{Al}_{2} \mathrm{O}_{3} \leftrightarrow 2 \mathrm{Al}_{\mathrm{g}} \uparrow+3 \mathrm{O}_{\mathrm{g}} \uparrow ; K_{2}=\left(P_{\mathrm{Al}}\right)^{2} \cdot\left(P_{\mathrm{O}}\right)^{3} .
$$

The lower aluminum oxides $\mathrm{AlO}, \mathrm{Al}_{2} \mathrm{O}$, $\mathrm{Al}_{2} \mathrm{O}_{2}$ arise due to chemical interaction of the main components and exert no influence on the potential $\varepsilon$, since their content is substantially lower in the dissociation products of $\mathrm{Al}_{2} \mathrm{O}_{3}$ [7].

In the absence of the thermodynamical equilibrium $(\varepsilon \neq 0)$, the Schottky defects and the corresponding stoichiometry disturbance (destoichiometry) of the material are formed in the crystal bulk. The redox processes are described by quasi-chemical reactions with the corresponding equilibrium constants:

- the process of corundum reduction:

$$
\begin{gathered}
0^{*} \leftrightarrow \mathrm{O}_{\mathrm{g}} \uparrow+V_{\mathrm{O}}^{x} ; \quad K_{3}=P_{\mathrm{O}} \cdot\left[V_{\mathrm{O}}^{x}\right], \\
0^{*}+\left.\left.2 \mathrm{~A}\right|_{\mathrm{g}} \leftrightarrow 2 \mathrm{~A}\right|_{s} ^{x}+3 V_{\mathrm{O}}^{x} ; \\
K_{4}=\left(P_{\mathrm{Al}}\right)^{-2} \cdot\left[V_{\mathrm{O}}^{x}\right]^{3} ;
\end{gathered}
$$

- the process of corundum oxidation:

$$
\begin{gathered}
0^{*} \leftrightarrow V^{x_{\mathrm{Al}}}+\mathrm{Al}_{\mathrm{g}} \uparrow ; \quad K_{5}=\left(P_{\mathrm{Al}} \cdot\left[V_{\mathrm{Al}}^{x}\right] ;\right. \\
0^{*}+3 \mathrm{O}_{g} \leftrightarrow 3 \mathrm{O}^{x_{s}}+2 V_{\mathrm{Al}}^{x} ; \\
K_{6}=\left(P_{\mathrm{O}}\right)^{-3} \cdot\left[V_{\mathrm{Al}}^{x}\right]^{2} .
\end{gathered}
$$

where $0^{*}$ denotes the crystal matrix of the stoichiometric composition; $\mathrm{O}_{s}^{x}, \mathrm{Al}^{x}$ are the oxygen and aluminum ions with zero effective charge in the matrix; $V_{A l}^{x}, V_{O}^{x}$, the Schottky defects (cation and anion vacancies with zero effective charge); [ $\left.V^{x} \mathrm{O}\right],\left[V^{x}{ }_{\mathrm{Al}}\right]$, the Schottky defects concentration; $K_{2} \ldots K_{5}$, the equilibrium constants of the corresponding quasi-chemical reactions; $P_{\mathrm{Al}}, P_{\mathrm{O}}$, the partial pressures of aluminum and oxygen vapors in the thermal dissociation products of the growing (annealed) crystal. 
The described process of defect formation under the influence of the high-temperature medium terminates when the potential $\varepsilon$ becomes equal to zero:

$$
R T \cdot \ln \left[\left(\frac{P_{\mathrm{Al}}}{P^{*}{ }^{\frac{2}{3}}}\right)^{\cdot} \cdot\left(\frac{P^{*_{\mathrm{O}}}}{P_{\mathrm{O}}}\right)\right]=0 .
$$

Generally, taking into account the constant of aluminum oxide thermal dissociation, we can write the redox chemical potential $\varepsilon$ in the form:

$$
\begin{gathered}
\varepsilon=R T \cdot \ln \left[\frac{\left(P_{\mathrm{Al}}^{0}\right)^{2 / 3} \cdot K_{2}^{1 / 3}}{P_{\mathrm{O}}^{0} \cdot\left(P_{\mathrm{Al}}^{*}\right)^{4 / 3}}\right]= \\
=\frac{2}{3} R T \cdot \ln \left[\frac{\left(P_{\mathrm{Al}}^{0}\right)^{2 / 3} \cdot\left(P_{\mathrm{O}}^{*}\right)^{2}}{P_{\mathrm{O}}^{0} \cdot K_{2}^{1 / 3}}\right] .
\end{gathered}
$$

The functional relationship between the potential of the high-temperature medium and the equilibrium concentration of the Schottky defects in a crystal being grown (being annealed) is of practical interest. When the crystal is in thermodynamic equilibrium with its environment, the partial vapor pressures of aluminum and oxygen in that environment are equal to those in saturated thermal dissociation products of the crystal under annealing $\left(P_{\mathrm{Al}}^{*}=P_{\mathrm{Al}}, P^{*} \mathrm{O}=\right.$ $\left.P_{\mathrm{O}}\right)$. By using Eq. (2), this allows to simplify mathematical expression (8) to:

$$
\varepsilon=2 R T \cdot \ln \left[\frac{P^{*_{\mathrm{O}}}}{P^{0_{\mathrm{O}}}}\right]=\frac{4}{3} R T \cdot \ln \left[\frac{P^{0_{\mathrm{Al}}}}{P^{*} \mathrm{Al}}\right]
$$

and to transform:

$$
\begin{gathered}
P_{\mathrm{O}}^{*}=P_{\mathrm{O}}^{0} \cdot \exp (\varepsilon / 2 R T) ; \\
P_{\mathrm{Al}}^{*}=P_{\mathrm{Al}}^{0} \cdot \exp (-3 \varepsilon / 4 R T) .
\end{gathered}
$$

Eqs. (3)-(6) and Eq. (10) testify to the existence of a functional relationship between the potential $\varepsilon$ and the equilibrium concentration of anionic and cationic vacancies in corundum crystal:

$$
\begin{gathered}
\quad\left[V_{\mathrm{O}}^{x}\right]=\frac{K_{3}}{P_{\mathrm{O}}^{0}} \cdot \exp (-\varepsilon / 2 R T)= \\
=K_{4}^{1 / 3}\left(P_{\mathrm{Al}}^{0}\right)^{2 / 3} \cdot \exp (-\varepsilon / 2 R T) ; \\
{\left[V_{\mathrm{Al}}^{x}\right]=\frac{K_{5}}{P_{\mathrm{Al}}^{0}} \cdot \exp (3 \varepsilon / 4 R T)=} \\
=K_{6}^{1 / 2}\left(P_{\mathrm{O}}^{0}\right)^{3 / 2} \cdot \exp (3 \varepsilon / 4 R T) .
\end{gathered}
$$

Using the known values of the coefficients $K \ldots K_{6}$ we can practically apply expressions (11) and (12) while estimating the redox potential for the high-temperature technological medium at the given value of stoichiometry disturbance for the real crystal, as well as for predicting the Schottky defect concentration in the crystal at the given potential value $\varepsilon$.

\section{Analysis of neutral synthesis conditions}

Depending on the technology for the obtaining of corundum single crystals, there are used gaseous media with different chemical potential. As a rule, sapphire is grown in a neutral medium, i.e. in vacuum or inert gas (Kyropoulos method, HDSM), activated corundum crystals are grown either in oxidative (Verneuil method) or in reductive (Czochralski method, HDSM) gaseous media.

Vacuum is a conventional medium for the growth and high-temperature annealing of corundum single crystals in apparatuses in which molybdenum components and tungsten heater are used. Based on the results of the investigation of high-temperature gaseous medium composition in the systems Mo- $-\mathrm{Al}_{2} \mathrm{O}_{3}$ and $\mathrm{W}-\mathrm{Al}_{2} \mathrm{O}_{3}$ ) [8], calculated were the values of $\varepsilon$ for the conditions of vacuum annealing of corundum single crystals. The obtained results (Table 1) allow to conclude that, within the temperature interval from $2000 \mathrm{~K}$ to $2300 \mathrm{~K}$, vacuum annealing of corundum realized by means of technological equipment with tungsten and molybdenum components is weakly reductive $(\varepsilon \approx-25 \ldots+25 \mathrm{~kJ} / \mathrm{mol})$. The value of the potential $\varepsilon$ does not depend on the temperature of technological treatment.

For the growth of doped corundum single crystals by Czochralsky method, inert gas (argon) is used as a gaseous medium. In this case the chemical potential of the growth medium is defined by the mass transfer of the products of melt dissociation in the crystallization zone. The flow of the products of $\alpha-\mathrm{Al}_{2} \mathrm{O}_{3}$ dissociation into the medium is described by the equation [9]:

$$
J_{i}=\frac{\alpha \cdot\left(P_{i}^{0}-P_{i}^{\infty}\right)}{\left(1 / \beta_{i}^{m}+1 / \beta_{i}^{d}\right)}, \operatorname{part} \cdot \mathrm{cm}^{-2} \cdot s^{-1},
$$

where $\alpha$ is the coefficient of accommodation; $i$, the component of the vapor $(\mathrm{Al}, \mathrm{O}$, $\left.\mathrm{O}_{2}, \mathrm{Al}_{2} \mathrm{O}, \mathrm{Al}_{2} \mathrm{O}_{3}\right) ; P_{i}{ }^{0}$, the pressure of the dissociation products over the melt (Torr); 
Table 1. Chemical potential of high-temperature medium for technological systems at vacuum annealing (residual pressure of about $0.015 \mathrm{~Pa}$ ) of corundum single crystals

\begin{tabular}{|c|c|c|c|c|c|}
\hline \multicolumn{2}{|c|}{ Technological system } & \multicolumn{4}{|c|}{ Temperature of gaseous medium } \\
\hline & & $2000 \mathrm{~K}$ & $2100 \mathrm{~K}$ & $2200 \mathrm{~K}$ & $2300 \mathrm{~K}$ \\
\hline \multirow[t]{2}{*}{$\mathrm{Al}_{2} \mathrm{O}_{3}$} & $P_{\mathrm{O}}(\mathrm{atm})$ & $9.9 \cdot 10^{-9}$ & $4.6 \cdot 10^{-8}$ & $2.3 \cdot 10^{-7}$ & $1.2 \cdot 10^{-6}$ \\
\hline & $P_{\mathrm{Al}}(\mathrm{atm})$ & $6.7 \cdot 10^{-9}$ & $2 \cdot 10^{-8}$ & $9.5 \cdot 10^{-8}$ & $7.9 \cdot 10^{-7}$ \\
\hline \multirow{3}{*}{$\mathrm{W}-\mathrm{Al}_{2} \mathrm{O}_{3}$} & $P_{\mathrm{O}}(\mathrm{atm})$ & $8.3 \cdot 10^{-8}$ & $9.7 \cdot 10^{-8}$ & $1.9 \cdot 10^{-7}$ & $8.0 \cdot 10^{-7}$ \\
\hline & $P_{\mathrm{Al}}(\mathrm{atm})$ & $8.0 \cdot 10^{-8}$ & $9.8 \cdot 10^{-8}$ & $2.4 \cdot 10^{-7}$ & $9.3 \cdot 10^{-7}$ \\
\hline & $\varepsilon(\mathrm{kJ} / \mathrm{mol})$ & 26 & 24 & -7 & -16 \\
\hline \multirow[t]{3}{*}{$\mathrm{Mo}-\mathrm{Al}_{2} \mathrm{O}_{3}$} & $P_{\mathrm{O}}(\mathrm{atm})$ & $9.8 \cdot 10^{-9}$ & $5.2 \cdot 10^{-8}$ & $9.6 \cdot 10^{-8}$ & $5.8 \cdot 10^{-7}$ \\
\hline & $P_{\mathrm{Al}}(\mathrm{atm})$ & $9.8 \cdot 10^{-9}$ & $5.0 \cdot 10^{-8}$ & $2.0 \cdot 10^{-7}$ & $9.7 \cdot 10^{-7}$, \\
\hline & $\varepsilon(\mathrm{kJ} / \mathrm{mol})$ & 0 & 3 & -32 & -28 \\
\hline
\end{tabular}

$P_{i}^{\infty}$, the pressure of the dissociation products beyond the diffusion zone (Torr).

In the calculations it was assumed that $\alpha=1$ and $P_{i}^{0}>P_{i}^{\infty}$; the $P_{i}^{0}$ values were taken from [7]; $\beta_{i}{ }^{m}$ and $\beta_{i}{ }^{d}$, the kinetic evaporation coefficients of the vapor components in molecular and diffusive regimes, respectively:

$\beta_{i}^{m}=$

$=3.513 \cdot 10^{22} \cdot \frac{1}{\sqrt{M_{i} \cdot T}}$, part. $\cdot$ torr $^{-1} \cdot \mathrm{cm}^{-2} \cdot \mathrm{s}^{-1}$,

$\beta_{i}^{d}=$

$=9.656 \cdot 10^{18} \cdot \frac{D_{i}}{\delta T}$, part. $\cdot \operatorname{torr}^{-1} \cdot \mathrm{cm}^{-2} \cdot \mathrm{s}^{-1}$,

where $M_{i}$ is the mass number of the dissociation product for $\mathrm{Al}_{2} \mathrm{O}_{3}$ melt ( $\mathrm{Al}$, $\mathrm{O}$ etc.); $T$, the temperature, $\mathrm{K} ; \delta$, the diffusion layer thickness, $\mathrm{cm}$; $D_{i}$, the diffusion coefficient of the particle ( $\mathrm{Al}$, $\mathrm{O}$ etc.) in the me$\operatorname{dium}(\mathrm{Ar}), \mathrm{cm}^{2} / \mathrm{s}$.

The value of $D_{i}$ was determined from the relation [10]:

$D_{i}=$

$=1.8583 \cdot 10^{-3} \frac{T^{3 / 2} \cdot \sqrt{1 / M_{k}+1 / M_{m}}}{P_{m} \sigma_{(k-m)}^{2} \cdot \Omega_{D}}, \mathrm{~cm}^{2} \mathrm{~s}^{-1}$;

where $P_{m}$ is the total pressure of the medium, atm; $\sigma_{(k-m)}$, the intermolecular distance; $\Omega_{D}$, the integral of collisions. For calculating $\sigma_{(k-m)}$ and $\Omega_{D}$ there used the reference data $[10,11]$.

It is obvious that at $\beta^{m}>>\beta^{d}$. Eq. (13) describes diffusion of the melt dissociation products through the medium (Ar), whereas at $\beta^{m}<\beta^{d}$ it corresponds to the highest theoretical rate of evaporation that can be achieved in vacuum. The influence of the medium pressure becomes noticeable at pressures higher than the equilibrium pressure of $\mathrm{Al}_{2} \mathrm{O}_{3}$ vapor. On the basis of calculations is it possible to conclude that the value of reducing potential of the medium is practically neutral $(\varepsilon \approx-10 . . .-15 \mathrm{~kJ} / \mathrm{mol})$ at the inert gas pressures $P_{m} \geq 10 \mathrm{~Pa}$.

\section{Analysis of carbon-containing gaseous medium}

The anionic sublattice of corundum is effectively influenced by the high-temperature carbon-containing medium. In this medium the oxygen contained in the products of thermal dissociation of the crystal interacts with carbon oxide, whereas the graphite present in the high-temperature zone reduces carbon dioxide [12]:

$$
\begin{gathered}
\mathrm{xCO}+\mathrm{Al}_{2} \mathrm{O}_{3} \leftrightarrow \mathrm{Al}_{2} \mathrm{O}_{(3-\mathrm{x})}\left(V_{\mathrm{O}}\right)_{x}+\mathrm{xCO}_{2} \uparrow,(1 \\
\mathrm{O}+\mathrm{CO} \leftrightarrow \mathrm{CO}_{2} ; K_{18}=\frac{P^{*} \mathrm{CO}_{2}}{P^{*} \mathrm{CO} \cdot\left(P^{*}\right)^{2}} ; \\
\mathrm{CO}_{2}+\mathrm{C} \leftrightarrow 2 \mathrm{CO} ; K_{19}=\frac{\left(P_{\mathrm{CO}}^{*}\right)^{2}}{P_{\mathrm{CO}_{2}}^{*}}
\end{gathered}
$$

where $K_{18}$ and $K_{19}$ are the equilibrium constants of the corresponding reactions; $P^{*} \mathrm{co} 2, P^{*} \mathrm{CO}, P^{*}$, the equilibrium partial pressures of the gaseous medium components.

The total pressure $\left(P_{t o t}\right)$ of gas in the closed carbon-containing system is defined by the partial pressures of carbon oxide $\left(P_{\mathrm{CO}}\right)$ and carbon dioxide $\left(P_{\mathrm{CO} 2}\right)$. The oxy- 
Table 2. Equilibrium partial oxygen pressure $\left(P_{\mathrm{O}}^{*}\right)$ in $\left[\mathrm{O}-\mathrm{CO}-\mathrm{CO}_{2}-\mathrm{C}\right]$ closed system and in saturated vapors of corundum thermal dissociation products $\left(P_{O}^{0}\right)$ at different temperatures $(T)$ and pressures $\left(P_{t o t .}\right)$ of high-temperature technological medium

\begin{tabular}{|c|c|c|c|c|c|c|c|}
\hline \multirow[t]{2}{*}{$T, \mathrm{~K}$} & \multicolumn{6}{|c|}{$P_{\mathrm{O}}^{*}$, atm. } & \multirow[t]{2}{*}{$P_{\mathrm{O}}^{0}$, atm. } \\
\hline & $\begin{array}{c}P_{\text {tot. }}= \\
0.01 \text { atm. }\end{array}$ & $\begin{array}{c}P_{\text {tot. }}= \\
0.1 \text { atm. }\end{array}$ & $\begin{array}{c}P_{\text {tot. }}= \\
0.5 \text { atm. }\end{array}$ & $\begin{array}{c}P_{\text {tot. }}= \\
1.0 \mathrm{~atm} .\end{array}$ & $\begin{array}{c}P_{\text {tot. }}= \\
1.5 \text { atm. }\end{array}$ & $\begin{array}{c}P_{\text {tot. }}= \\
10.0 \mathrm{~atm} .\end{array}$ & \\
\hline 1800 & $1.7 \cdot 10^{-14}$ & $1.7 \cdot 10^{-13}$ & $8.7 \cdot 10^{-13}$ & $1.7 \cdot 10^{-12}$ & $3.5 \cdot 10^{-12}$ & $1.7 \cdot 10^{-11}$ & $2.0 \cdot 10^{-10}$ \\
\hline 1900 & $5.7 \cdot 10^{-14}$ & $5.6 \cdot 10^{-13}$ & $2.8 \cdot 10^{-12}$ & $5.6 \cdot 10^{-12}$ & $8.4 \cdot 10^{-12}$ & $5.6 \cdot 10^{-11}$ & $1.4 \cdot 10^{-9}$ \\
\hline 2000 & $2 \cdot 10^{-13}$ & $2.1 \cdot 10^{-12}$ & $1.1 \cdot 10^{-11}$ & $2.1 \cdot 10^{-11}$ & $3.2 \cdot 10^{-11}$ & $2.1 \cdot 10^{-10}$ & $9.9 \cdot 10^{-9}$ \\
\hline 2100 & $5.4 \cdot 10^{-13}$ & $5.4 \cdot 10^{-12}$ & $2.7 \cdot 10^{-11}$ & $5.4 \cdot 10^{-11}$ & $8.2 \cdot 10^{-11}$ & $5.4 \cdot 10^{-10}$ & $4.8 \cdot 10^{-8}$ \\
\hline 2200 & $7.7 \cdot 10^{-13}$ & $1.4 \cdot 10^{-11}$ & $7.4 \cdot 10^{-11}$ & $1.5 \cdot 10^{-10}$ & $2.2 \cdot 10^{-10}$ & $1.5 \cdot 10^{-9}$ & $2.3 \cdot 10^{-7}$ \\
\hline
\end{tabular}

Table 3. Reducing potential $\varepsilon$ of annealing medium for closed carbon-containing system as a function of temperature $(T)$ and total gas pressure $\left(P_{t o t}\right)$ in working space

\begin{tabular}{||c|c|c|c|c|c|c||}
\hline \multirow{2}{*}{$T, \mathrm{~K}$} & \multicolumn{5}{|c||}{$\varepsilon, \mathrm{kJ} / \mathrm{mol}$} \\
\cline { 2 - 7 } & $P_{\text {tot. }}=0.01 \mathrm{~atm}$ & $P_{\text {tot. }}=0.1 \mathrm{~atm}$ & $P_{\text {tot. }}=0.5 \mathrm{~atm}$ & $P_{\text {tot. }}=1.0 \mathrm{~atm}$ & $P_{\text {tot. }}=1.5 \mathrm{~atm}$ & $P_{\text {tot. }}=10 \mathrm{~atm}$ \\
\hline 1800 & -240 & -211 & -162 & -142 & -120 & -74 \\
1900 & -319 & -247 & -196 & -164 & -162 & -102 \\
2000 & -357 & -281 & -226 & -204 & -190 & -128 \\
2100 & -397 & -317 & -260 & -236 & -222 & -156 \\
2200 & -460 & -354 & -294 & -268 & -254 & -184 \\
\hline
\end{tabular}

gen partial pressure in the gaseous medium $\left(P^{*} \mathrm{O}\right.$ is negligible, therefore $P_{t o t}$ is:

$$
P_{\text {tot }} \approx P_{\mathrm{CO}}+P_{\mathrm{CO}_{2}}
$$

The joint solution of Eqs. (18-20) allows to determine the value of partial pressure for oxygen in the gaseous medium of the system [O-CO- $\mathrm{CO}_{2}-\mathrm{C}$ ] (Table 2).

The reducing potential of the high-temperature carbon-containing medium for the closed system (Table 3 ) was calculated using the formula (9) provided that $P^{*}$ Al value was equal to the equilibrium partial pressure of aluminum at equilibrium of $\left[\mathrm{Al}-\mathrm{Al}_{4} \mathrm{C}_{3}-\mathrm{C}\right]$ system.

We were solving the problem of evaluation of the potential $\varepsilon$ in the reducing carbon medium for the growth of corundum single crystals by Czochralski method. The leucosapphire crystals were grown from Mo crucible in Ar-atmosphere (0.11 MPa) under HF-heating of a graphite heater. The optical absorption of the grown crystal in the UVregion of the spectrum (Fig. 1) was studied using a spectrophotometer KSVU-2. The anionic vacancy density was calculated from the Smakula formula, taking into account the bands intensity of the optical absorption at $f 206 \mathrm{~nm}, 225 \mathrm{~nm}$ and $255 \mathrm{~nm}$ wave-

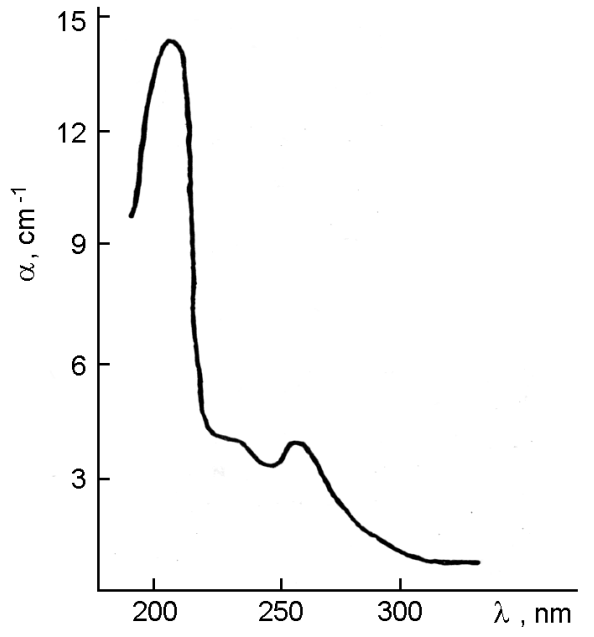

Fig. 1. UV-absorption of leucosapphire grown by Czochralski method in carbon-containing medium.

lengths corresponding to the $F$ and $F^{+}$centers of the optical absorption [4, 13]:

$$
N=\frac{0.87 \cdot 10^{17} \cdot \alpha \cdot H \cdot n}{f \cdot\left(2+n^{2}\right)^{2}}\left[\mathrm{~cm}^{-3}\right],
$$

where $\alpha$ is the absorption coefficient at the maximum of the corresponding wave range $\left[\mathrm{cm}^{-1}\right] ; f$, the intensity of the oscillator; $H$, the halfwidth of the absorption band $[\mathrm{eV}]$; 
Table 4. Main characteristics $\left(T, P_{\mathrm{O}}^{0}, P_{\mathrm{O}}^{*}, P_{\mathrm{Al}}^{0}, P_{\mathrm{Al}}^{*}\right)$ of high-temperature annealing medium of corundum single crystals in saturated vapors of metallic aluminum, equilibrium constant of quasi-chemical reaction $\left(K_{3}\right)$ and anionic vacancy concentration $\left(\left[V_{\mathrm{O}}\right]\right)$ obtained experimentally

\begin{tabular}{|c|c|c|c|c|c|c|c|}
\hline \multirow[t]{2}{*}{$T, \mathrm{~K}$} & \multicolumn{4}{|c|}{ Partial pressure $P_{i}$, atm } & \multirow{2}{*}{$\begin{array}{l}\text { Calculated } \\
\varepsilon, \mathrm{kJ} / \mathrm{mol}\end{array}$} & \multicolumn{2}{|c|}{ Experimental } \\
\hline & $P_{\mathrm{O}}^{0}$ & $P_{\mathrm{Al}}^{0}$ & $P_{0}^{*}$ & $P_{\mathrm{Al}}^{*}$ & & {$\left[V_{\mathrm{O}}\right], \mathrm{cm}^{-3}$} & $K_{3}$ \\
\hline 1973 & $4.71 \cdot 10^{-9}$ & $2.95 \cdot 10^{-9}$ & $3.36 \cdot 10^{-13}$ & $4.63 \cdot 10^{-3}$ & -313 & $5,99 \cdot 10^{16}$ & $2.135 \cdot 10^{4}$ \\
\hline 2043 & $1.72 \cdot 10^{-8}$ & $1.05 \cdot 10^{-8}$ & $1.85 \cdot 10^{-12}$ & $8,71 \cdot 10^{-3}$ & -310 & $1.71 \cdot 10^{17}$ & $2.805 \cdot 10^{5}$ \\
\hline 2100 & $4.61 \cdot 10^{-8}$ & $2.75 \cdot 10^{-8}$ & $6.82 \cdot 10^{-12}$ & $1.41 \cdot 10^{-2}$ & -308 & $3.51 \cdot 10^{17}$ & $1.898 \cdot 10^{6}$ \\
\hline 2153 & $1.09 \cdot \cdot 10^{-7}$ & $6.38 \cdot 10^{-8}$ & $2.16 \cdot 10^{-11}$ & $2,16 \cdot 10^{-2}$ & -305 & $5.13 \cdot 10^{17}$ & $8.514 \cdot 10^{6}$ \\
\hline 2273 & $6.55 \cdot 10^{-7}$ & $3.65 \cdot 10^{-7}$ & $2.38 \cdot 10^{-10}$ & $5.23 \cdot 10^{-2}$ & -299 & $4.49 \cdot 10^{17}$ & $9.316 \cdot 10^{7}$ \\
\hline
\end{tabular}

$N$, the number of the color centers in a unit of the crystal volume $\left[\mathrm{cm}^{-1}\right] ; n$, the refractive index of corundum calculated accounting the dispersion [14].

Non-stoichiometric anion vacancies are effective electron traps if their excess charge has no impurity compensation. They stabilize in the corundum lattice as $F$ - and $F^{+}$-centers. Equation (14) defines their total density in the crystal under investigation as:

$$
\begin{gathered}
{\left[V_{O}\right]=[F]+\left[F^{+}\right]=} \\
=\left(1.86 \cdot \alpha_{206}+0.875 \cdot \alpha_{225}+\right. \\
\left.+0.5 \cdot \cdot \alpha_{255}\right) \cdot 10^{16}\left[\mathrm{~cm}^{-3}\right] .
\end{gathered}
$$

As a result of the low partial pressure of the oxygen in the growth atmosphere, we obtain anionic non-stoichiometry of the corundum produced in the carbon- containing medium. This is due to the reduction of carbon dioxide by graphite heater and subsequent interaction of carbon oxide with the oxygen contained in the products of $\mathrm{Al}_{2} \mathrm{O}_{3}$ thermal dissociation. The same corundum defects are formed in the process of its annealing in saturated Al vapor. This effect was used for determining the equilibrium constants $K_{3}, K_{4}$ and evaluating potential $\varepsilon$ of the carbon-contained growth medium.

The sapphire samples $\left(1.5 \times 15 \times 15 \mathrm{~mm}^{3}\right)$ were subjected to annealing in sealed Mocapsules in the presence of metallic aluminum at $2000 \ldots 2300 \mathrm{~K}$ for $10 \mathrm{~h}$. The $F$-center for each of the annealed samples was investigated using the spectrum system KSVU-2. From the obtained experimental data the $\left[V_{\mathrm{O}}\right]$ center concentrations for each of these samples was determined according to equation (22). Those concentrations correspond to the equilibrium concentrations of the anionic vacancies for specific conditions (Table 4).
The solution of Equation (11) for the conditions of corundum annealing in saturated vapors of metallic aluminum, and the use of the experimentally obtained data on the equilibrium concentration of the anionic vacancies corresponding to these conditions allows to find the coefficients $K_{3}$ for $2000 . .2300 \mathrm{~K}$ temperature range (see Table 4 ).

The values of $\log \left(P_{O}^{0}\right), \quad \log \left(P_{A 1}^{0}\right)$, $\log \left(P_{O}^{*}\right)$ and $\log \left(P_{A l}^{*}\right)$ were calculated using the polynomial approximation of the data given in [7]:

$$
\begin{gathered}
\log \left(P_{\mathrm{O}}^{0}\right)=1.6525 \cdot 10^{-9} T^{3}-1.4258 \cdot 10^{-5} T^{2}+ \\
+4.5302 \cdot 10^{-2} T-54.897 \\
\log \left(P^{0} \mathrm{Al}\right)= \\
=1.8606 \cdot 10^{-9} \cdot T^{3}-1.5613 \cdot 10^{-5} \cdot T^{2}+ \\
+4.8069 \cdot 10^{-2} \cdot T-56.884 ; \\
\log \left(P_{\mathrm{O}}^{*}\right)=-2.3655 \cdot 10^{-12} \cdot T^{4}+ \\
+2.1475 \cdot 10^{-8} \cdot T^{3}-7.731 \cdot 10^{-5} \cdot T^{2}+ \\
+0.138 \cdot T-112.69 ; \\
\log \left(P_{\mathrm{Al}}^{*}\right)=-5.078 \cdot 10^{-13} \cdot T^{4}+ \\
+5.179 \cdot 10^{-9} \cdot T^{3}-2.095 \cdot 10^{-5} \cdot T^{2}+ \\
+4.1834 \cdot 10^{-2} \cdot T-35.42
\end{gathered}
$$

The experimental values of the equilibrium constant $K_{3}$ can be approximated by the exponential law [15]:

$$
K=A \cdot \exp \left(-E_{V} / R T\right),
$$

and the equation for the dependence of the equilibrium concentration of anionic vacancies in the crystal $\left[V_{\mathrm{O}}^{x}\right]$ on the value of the reducing chemical potential $(\varepsilon)$ is written in the form:

$$
\left[V_{\mathrm{O}}^{x}\right]=A_{1}\left(P_{\mathrm{O}}^{0}\right)^{-1} \exp \left[-\left(2 E_{V}+\varepsilon\right) / 2 R T\right],
$$


where $E_{V}=1047 \mathrm{~kJ} / \mathrm{mol} ; A_{1}=1.44 \cdot 10^{32}$ $\left[\mathrm{atm}^{-1} \cdot \mathrm{cm}^{-3}\right]$, the value of approximation 0.99 . Technical difficulties in determination of the partial pressure of aluminum and oxygen vapor in the gaseous medium of the technological system do not permit to analytically calculate the potential $\varepsilon$ for real technological process. Therefore, the chemical potential of the high-temperature gaseous medium can be estimated by the action of the medium on the crystal [16]. The value of the effective reducing chemical potential of the high-temperature carbon-containing medium can be estimated as follows:

$$
\varepsilon=-\left[2 E_{V}+2 R T \cdot \ln \left(\frac{\left[V_{\delta}^{\chi}\right] \cdot P_{\mathrm{O}}^{0}}{A_{1}}\right)\right] .
$$

Reduction potential of the crystallization medium for the process with a graphite heater $(\varepsilon=-285 \mathrm{~kJ} / \mathrm{mol}$. at $T=2350 \mathrm{~K})$ can be estimate using the values of the coefficients $\left(E_{V}, A_{1}\right)$, concentration of the $\left[V_{\mathrm{O}}\right]$-centers in the grown crystals $\left(2 \cdot 10^{17} \mathrm{~cm}^{-3}\right)$ and equation (25).

Such a high reducing potential is due to the low oxygen ratio in the technological medium $\left(P_{\mathrm{O}}^{*}=3.15 \cdot 10^{-9} \mathrm{~Pa}\right)$ and it leads to disturbance of anionic stoichiometry of the melt and the growing crystal. In this case, we have a uniform distribution of anionic vacancies in the crystal what makes it possible to use these vacancies for forming the active optical centers.

At present there is used the technology of sapphire growing in a reducing atmosphere by the method of horizontal directional crystallization [17]. The optical absorption spectrum of the sapphire grown in $(\mathrm{Ar}+\mathrm{CO})$ gaseous medium at pressures of 2-140 kPa contains the optical band of $F$-centers with the absorption maximum at the wavelength of $206 \mathrm{~nm}$ (Fig. 2). The intensity of this band grows as the pressure of the protective gaseous medium rises.

Concentration of $F$-centers in crystals grown under pressure $\sim 2 \mathrm{kPa}$ is $[F] \approx 1 \cdot 10^{16} \mathrm{~cm}^{-3}$ (Eq. (22)). Concentration increase till $[F] \approx(3 . .8) \cdot 10^{16} \mathrm{~cm}^{-3}$ in crystals grown under pressure $20-140 \mathrm{kPa}$. In accordance with the equation (25), chemical potential for $[\mathrm{Ar}-\mathrm{CO}-\mathrm{C}]$ open system $\varepsilon=-170 \mathrm{~kJ} / \mathrm{mol}$ corresponds for the gas-medium pressure $2 \mathrm{kPa}$ and $\varepsilon=-250 \mathrm{~kJ} / \mathrm{mol}$ for pressure $\sim 140 \mathrm{kPa}$.

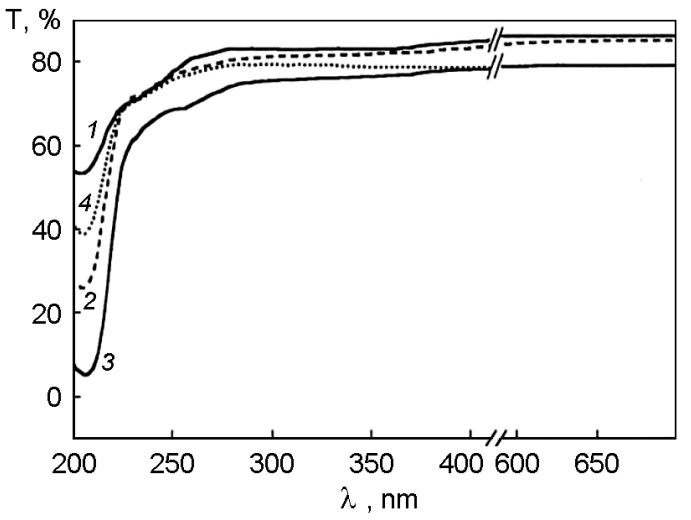

Fig. 2. Optical transmission spectrum of sapphire grown in $(\mathrm{Ar}+\mathrm{CO})$ gaseous medium under pressures of $2,20,140 \mathrm{kPa}$ (curves $1-3$, respectively); curve $4-$ after high-temperature annealing of the crystal grown under pressure of $140 \mathrm{kPa}$. The samples thickness is $6 \mathrm{~mm}$ [17].

\section{Conclusions}

Proposed is a method for evaluation of the redox potential of the medium for the growth and annealing of corundum single crystals. Disturbance of the crystal anionic stoichiometry in the high-temperature carbon-containing medium is shown to be caused by low partial pressure of oxygen over the crystal surface due to the interaction of the products of corundum thermal dissociation with carbon oxide contained in the growth (annealing) medium.

The chemical potential values for various gas growth (annealing) medium can be represented as follows:

- $\left[\mathrm{O}-\mathrm{CO}-\mathrm{CO}_{2}-\mathrm{C}\right]$ medium in closed system $(\varepsilon \approx-450 \ldots-75 \mathrm{~kJ} / \mathrm{mol})$;

- saturated vapors of aluminum $(\varepsilon \approx-$ 310...-300 kJ/mol);

- $[\mathrm{Ar}-\mathrm{CO}-\mathrm{C}]$ medium in open system $(\varepsilon \approx-290 \ldots-170 \mathrm{~kJ} / \mathrm{mol})$;

- vacuum (residual pressure about $0.01 \mathrm{~Pa}, \varepsilon \approx-25 . .+25 \mathrm{~kJ} / \mathrm{mol}$ );

- argon as a gaseous medium $(\varepsilon \approx-15 \ldots-$ $10 \mathrm{~kJ} / \mathrm{mol}$ );

- saturated vapors of aluminum oxide $(\varepsilon=0)$;

- $\operatorname{air}(\varepsilon \approx+500 \mathrm{~kJ} / \mathrm{mol})$.

Under the known technological conditions the functional dependence $\left[V_{O}\right]=f(\varepsilon)$ obtained on the basis of this evaluation makes it possible to predict the crystal quality, to correct this technological process, as well as to investigate the conditions of the crystal structure formation in real systems. The same approach can be successfully used while growing other crystals. 


\section{References}

1. I.P.Babiychuk, V.S.Konevskiy, E.V.Krivonosov, L.A.Litvinov, Optik. Mechan.Promyshlenost, No. 4, 34 (1986).

2. D.V.Sandrejev, P.A.Arsenjev, Z.G.Marejeva et al., Kristal und Technik, 8, 957 (1976).

3. S.F.Kvjatkovskiy, V.S.Konevskiy, E.V.Krivonosov, L.A.Litvinov, Zh.Priklad.Spektr., 51, 90 (1969).

4. V.D.Lee, I.H.Grawford, J.Phys.Rev.B, 15, 4065 (1977).

5. V.B.Neustruev, Trans. Fiz. Inst. AN SSSR, 79, 3 (1974).

6. E.V.Krivonosov, Functional Materials, 1, 105 (1994).

7. I.S.Kulikov, Thermodynamics of Oxides, Metalurgiya, Moscow (1986) [in Russian].

8. I.Drowart, G.De Maria, R.P.Burns, M.G.Ingharm, J.Chem. Phys., 32, 1366 (1960).

9. O.Knakke, I.Stranskiy, Uspechi Fiziki Metallov, No. 3, 222 (1960).
10. S.Wasserman, Determination of Gases in Metals, Nauka, Moscow (1976) [in Russian].

11. R.Rid, Dj.Prauonic, T.Sherwud, Properties of Gases and Liquids, Chimiya, Leningrad (1982) [in Russian].

12. V.S.Konevskiy, E.V.Krivonosov, L.A.Litvinov, Izv.AN SSSR, Ser.Neorg. Mater., 25, 1486 (1989).

13. V.D.Evans, B.Stapelbrock, J.Phys.Rev. B, 18, 7089 (1978).

14. S.V.Grum-Grzhimailo, M.V.Klassen-Nekludova, Ruby and Sapphire, Nauka, Moscow (1974) [in Russian].

15. P.Kofstad, Nonstoichiometry Diffusion end Electrical Conductivity in Binary Metal Oxides, Central Institute for Industrial Research, Blindern, Olso, Norway, Wiley, New York (1972).

16. S.D.Vishnevsky, E.V.Krivonosov, L.A.Litvinov, Functional Materials, 10, 238 (2003).

17. A.Ya.Dan'ko, V.F.Tkachenko, N.S.Sidelnikova et al., Functional Materials, 11, 251 (2004). 